AperTO - Archivio Istituzionale Open Access dell'Università di Torino

\title{
Preface from the organizing chairs
}

\section{This is the author's manuscript}

Original Citation:

\section{Availability:}

This version is available http://hdl.handle.net/2318/1523288

since 2015-08-30T21:56:23Z

Publisher:

IEEE Computer Society

Published version:

DOI:10.1109/PDP.2014.5

Terms of use:

Open Access

Anyone can freely access the full text of works made available as "Open Access". Works made available under a Creative Commons license can be used according to the terms and conditions of said license. Use of all other works requires consent of the right holder (author or publisher) if not exempted from copyright protection by the applicable law. 


\section{Preface from the Organizing Chairs}

On behalf of the Organizing Committee we are pleased to welcome you to the $22^{\text {nd }}$ Euromicro International Conference on Parallel, Distributed, and Network-Based Processing (PDP 2014), organised by Computer Science Department of the University of Turin.

The University of Turin is one of the oldest and largest universities in Italy (founded in 1404), and has more than 2000 lecturers and professors. The University of Turin can count many notable alumni and faculty, including, in formal and physical sciences: Joseph-Louis Lagrange (born Giuseppe Luigi Lagrangia), Augustin Cauchy, Giuseppe Peano, Galileo Ferraris; in medicine: Salvador Luria, Renato Dulbecco and Rita Levi-Montalcini (Nobel Prizes); in philosophy and literature: Erasmus of Rotterdam, Primo Levi, Cesare Pavese, Umberto Eco. The Computer Science department was founded in 1971 and today has 37 professors (12 full, 23 associate), 38 permanent researchers, 21 research fellows, and about $40 \mathrm{PhD}$ students. Their scientific activity covers a wide range of areas, including concurrency theory, parallel, distributed and high performance computing, and clouds.

The city of Turin (Italian: Torino) is an important business and cultural centre in northern Italy. It is capital of the Piedmont region, located mainly on the left bank of the Po River and surrounded by the western Alpine arch. The population of the urban area is estimated to be 1.7 million inhabitants. The city has a rich culture and history, and is known for its numerous art galleries, restaurants, churches, palaces, opera houses, piazzas, parks, gardens, theatres, libraries, museums and other venues. Turin is well known for its baroque, rococo, neo-classical, and Art Nouveau architecture. Many of the city's public squares, castles, gardens and elegant palazzi such as Palazzo Madama, were built in the 16th and 18th century, after the capital of the Duchy of Savoy (later Kingdom of Sardinia) was moved to Turin from Chambery (now in France), as part of the urban expansion.

Turin is sometimes called the "cradle of Italian liberty", for having been the birthplace and home of notable politicians and people who contributed to the Renaissance, such as Cavour, a leading figure in the movement toward Italian unification, and many of the protagonists of Italian political and social life in the 20th century, including Giovanni Giolitti, Luigi Einaudi, Antonio Gramsci, Piero Gobetti, and Palmiro Togliatti. The city used to be a major European political centre, being Italy's first capital in 1861 and home to the House of Savoy, the Italian royal family. The city currently hosts some of the best Italian universities, colleges, academies, lycea and gymnasia, such as the six-century-old University of Turin and the Turin Polytechnic. Prestigious and important museums, such as the Egyptian Museum and the Mole Antonelliana are also found in the city. Turin's several monuments and sights make it one of the world's top 250 tourist destinations. Turin is also well known as the home of the Shroud of Turin, the football teams Juventus F.C. and Torino F.C., the headquarters of automobile manufacturers FIAT, Lancia and Alfa Romeo, and as host of the 2006 Winter Olympics. Several International Space Station modules, such as Harmony and Columbus, were manufactured in Turin.

Organizing PDP 2014 has been a team effort. We would like to thank all the members of the Computer Science Department, and of the University of Turin in general, who have contributed so much of their time and enthusiasm to the running of PDP 2014. In particular we thank Marco Beccuti, Maurizio Drocco, Guilherme Peretti Pezzi, Fabio Tordini, Claudia Misale, Irfan Uddin, and Claudio Mattutino who actively participated in the organisation of PDP 2014.

We thank the University of Turin for providing the setting for PDP 2014 and "Turismo Torino" for their support with accommodation booking and events organization. We also thank the city of Turin, province of Turin, Piedmont region, and European Association of Theoretical Computer Science for their patronage of PDP 2014. 
Finally, we thank the PDP 2014 sponsors: NVidia Corporation, IBM Corporation, E4 Computer Engineering, Sistemi HS (HP ServiceOne expert).

We wish you an enjoyable stay in Turin.

Marco Aldinucci, Sergio Rabellino 